\title{
Cezary Szpytma
}

Politechnika Rzeszowska

cszpytma@prz.edu.pl

\section{Szkoły typu Open-Air: eksperymenty architektoniczno-pedagogiczne szkolnictwa w pierwszych dziesięcioleciach XX wieku}

\section{Summary \\ Open-Air Schools: Architectural and pedagogical experiments regarding schools in the early twentieth century}

The aim of the article is to present the contribution of Open-Air schools in the context of the evolution of the school environment and development of modern pedagogy. The article takes into account the historical context of evolution and the historical development of pedagogical ideas. The article focuses on the connection between pedagogy and architecture - regarding school, both disciplines are inextricably linked. Pedagogy is the theoretical foundation of teaching practice, implemented in an architectural space. The quality of this space is of great importance for learning outcomes. Consciously the design and architecture of a school creates something more than a simple housing for the process of education. It can create an environment for education and could strengthen that process in a synergistic manner. In reality, we can observe almost the opposite situation, when the school space, instead of comprehensively stimulating the students, becomes a materialized symbol of the oppressive nature of the educational system. Open-Air schools of the early twentieth century seem to be still an avant-garde and a model, which should be rediscovered. They offer the opportunity to develop social, emotional, and creative skills. These objectives are itemized by many as essential for education in the future.

Słowa kluczowe: architektura szkół, środowisko edukacji, środowisko szkół, zagadnienia interdyscyplinarne, szkoły Open-Air, eksperymenty pedagogiczne, pedagogika XX wieku

Keywords: architecture of schools, educational environment, school environment, interdisciplinary issues, Open-Air Schools, pedagogical experiments, pedagogy of XX century

\section{Wprowadzenie}

W XX wieku nie udało się wypracować uniwersalnego wzorca systemu oświaty. Do dnia dzisiejszego w systemach oświatowych poszczególnych krajów występują różnice, wynikające ze specyfiki lokalnych warunków społeczno-polityczno-gospodarczych dla ich rozwoju. Zwraca na to uwagę $\mathrm{S}$. Wołoszyn, podkreślając równocześnie ogólny, spójny kierunek dążeń i tendencji rozwojowych w krajach mających wspólny rodowód kulturowy (Wołoszyn 2003: 156). Wszystkie współczesne systemy oświaty w krajach rozwinię- 
tych powstawały w tym samym okresie i w dużej mierze wciąż bazują na rozwiązaniach XIX-wiecznych z początku swojego istnienia (Robinson 2010: 39-40, 101, 111; Śliwerski 2013; Ślusarczyk 2010: 186). Ta względna spójność systemów edukacji w krajach rozwiniętych pozwala na dokonanie syntetycznych podsumowań. Różnice natomiast dają możliwość analizowania skuteczności poszczególnych, czasami różnorodnych rozwiązań.

Burzliwa historia XX wieku była tym czynnikiem, który miał największy wpływ na ewolucję szkolnictwa tego okresu, a z dzisiejszej perspektywy, również na jego obecny kształt. Zaowocowała ona naprzemiennymi okresami „eksplozji oświatowych” i „kryzysów edukacyjnych" (Wołoszyn 2003: 156). Okresy, w których przeważała progresywna myśl pedagogiczna, przeplatały się z tymi, w których dominowały tendencje zachowawcze, a punkt ciężkości przenosił się w inne obszary związane z demokratyzacją i ujednolicaniem systemu (Wołoszyn 2003: 156).

Budynki szkolne są często uważane za zwierciadło epoki, w których powstawały: ,architektura szkół, zarówno ich wygląd zewnętrzny, jak i wewnętrzna dyspozycja przestrzenna jest w symbiotycznej relacji z [współczesnymi im - C.S.] poglądami na temat dzieciństwa, edukacji i społeczeństwa" (Burke, Grosvenor 2008: 12). Analizując historyczną ewolucję środowiska edukacji, warto zauważyć rolę, jaką odegrały w niej szkoły typu Open-Air z okresu przedwojennego. Pisząc o eksperymentach szkolnych z dziedziny architektury, nie sposób jednak nie odnieść się do ich kontekstu historycznego w obrębie nauk społecznych: pedagogiki, psychologii i socjologii. Przedstawienie wpływu szkół typu Open-Air na ewolucję przestrzeni środowiska szkolnego w świetle rozwoju myśli około-pedagogicznej oraz kontekstu historycznego tej ewolucji jest przedmiotem niniejszego artykułu.

\section{Narodziny idei szkoły Open-Air}

Początek stulecia zawsze skłania do dokonania bilansu dotychczasowych osiągnięć i porażek, do refleksji nad etapem rozwoju, w którym znalazła się cywilizacja i państwo; początek XX wieku był okresem głośnej krytyki dotychczasowych metod pedagogicznych i systemu szkolnictwa w ogóle (Wołoszyn 2003: 165). Zarzucano mu ,sztywną koszarowa organizację i atmosferę, sformalizowane metody, powodujące raczej bierność intelektualną uczniów i wymagające bardziej zapamiętywania aniżeli rozumienia wiedzy, oderwanie i izolowanie młodzieży od codziennego życia społecznego i kulturalnego" (Wołoszyn 2003: 165). Odpowiedzią na te zarzuty miało być znacznie bardziej liberalne Nowe Wychowanie, kładące nacisk na rozwój indywidualnych zainteresowań, wzmacnianie samodzielności, wspieranie autoedukacji, kształcenie poprzez działanie - najogólniej ujmując - szeroko rozumiane otwarcie tradycyjnego systemu edukacji (Wołoszyn 2003: 165). Idei tej nie udało się jednak przełożyć wprost na wymiar architektoniczny. Zdecydowała o tym skomplikowana i napięta atmosfera polityczno-gospodarcza, która stymulowała raczej rozwój cywilizacji przemysłowej (Wołoszyn 2003: 166). Prądy myślowe z początku wie- 
ku dotyczące szkolnictwa były szerzej realizowane w architekturze dopiero po I wojnie światowej.

Idea otwarcia szkoły zaczęła być praktykowana w inny, znacznie bardziej dosłowny sposób, jako nauka na dworze lub w budynku bez przegród między wnętrzem a zewnętrzem. Znów kluczową rolę odegrały realia - powszechnie panująca na początku wieku gruźlica, a później jej powojenna epidemia. Organizowanie szkół na świeżym powietrzu było pomysłem na zapewnienie środowiska higienicznego, dobrze doświetlonego i przewietrzanego (Crowley 1910: 330 za: Burke, Grosvenor 2008: 71). Otwartość szkoły miała w tym wypadku chronić zdrowe dzieci przed zachorowaniem, a dla zarażonych była w obliczu braku lekarstw jedyną formą terapii (Chatelet 2008: 107).

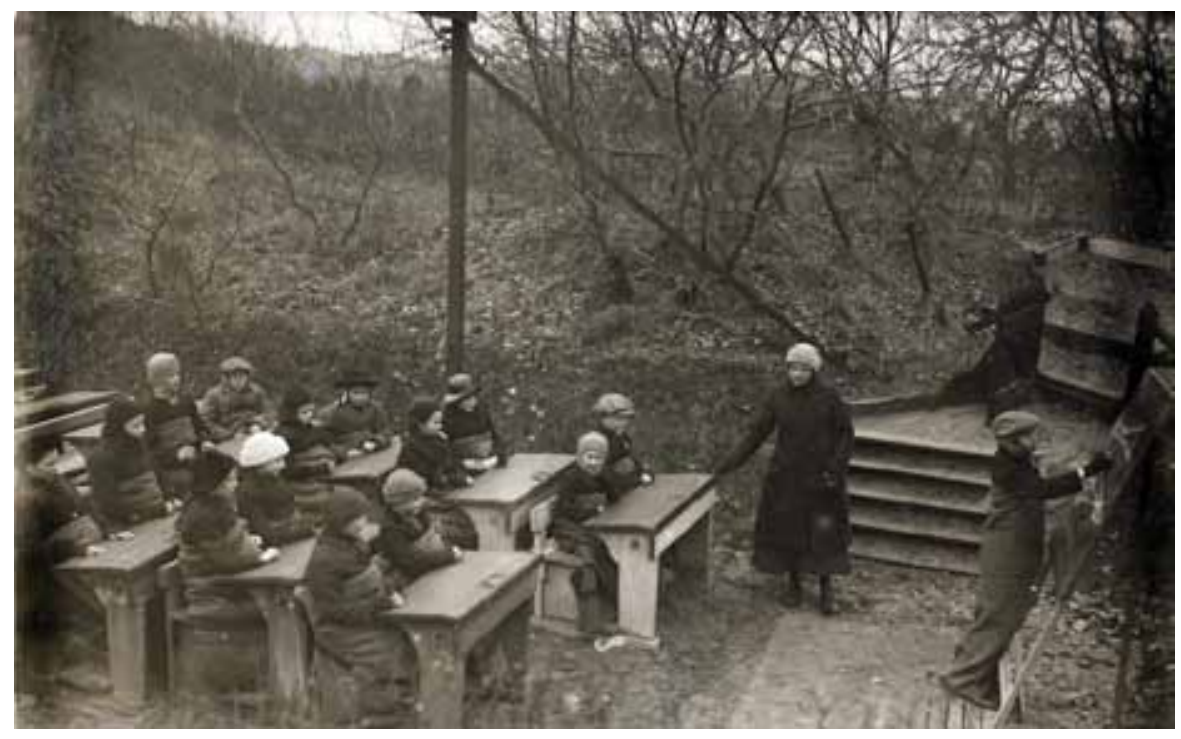

Fot. 1. Przykład radykalnego zastosowania idei Open-Air - szkoła na otwartym powietrzu w Holandii ${ }^{1}, 1918$ rok

Źródło: http://commons.wikimedia.org, lic. CC.

\section{Pierwsza szkoła typu Open-Air: Waldschule}

Prekursorskim rozwiązaniem szkoły Open-Air była Waldschule w Charlottenburg (będącego ówcześnie zachodnim przedmieściem Berlina) z 1904 roku. Szkoła przeznaczona była wyłącznie dla dzieci chorych. Na lokalizację wybrano działkę porośniętą lasem sosnowym (szkoła zawdzięcza mu nazwę), który miejscami wykarczowano w celu zapewnienia odpowiedniego nasłonecznienia. Centralną częścią szkoły był plac. Znajdowała się na nim wiata pełniąca funkcję plenerowej sali lekcyjnej oraz stołówki. Przy placu stał

1 Jest to szczególny przykład szkoły funkcjonującej bez architektury. 
drewniany budynek wejściowy, w którym mieściły się dwie sale lekcyjne o wymiarach 6 na 8 metrów i pokoje administracyjne. Sale wykorzystywane były zwłaszcza w okresach niesprzyjającej pogody, pełniły również funkcje bawialni i jadalni; wyposażone zostały w mobilne stoliki i krzesła w trzech rozmiarach.

Wokół placu rozlokowano pozostałe elementy programu funkcjonalnego: budynki lekcyjne, kuchnię z wydawalnią posiłków, magazyny, toalety oraz kompleks kąpielowo-szatniowy (Chatelet 2008: 109-110). Na placyku zlokalizowanym na zachód od zabudowań znajdowały się przyrządy gimnastyczne, a w nieznacznym oddaleniu, w części północnej zbudowano budynki służące do odpoczynku i terapii. Budynki wykonane zostały w prefabrykowanej drewnianej technologii, opracowanej z przeznaczeniem dla wojska. Pozwoliło to na błyskawiczną budowę szkoły w ciągu niespełna dwóch miesięcy. Szkoła odniosła spory sukces i w 1908 roku wniesiono drugi budynek szkolny, na południe od istniejącego, mieszczący trzy sale lekcyjne. Zaaranżowano miejsca do prowadzania praktycznych zajęć z ogrodnictwa i rolnictwa, wydzielono ogrodzoną dwumetrowym płotem przestrzeń do kąpieli słonecznych.

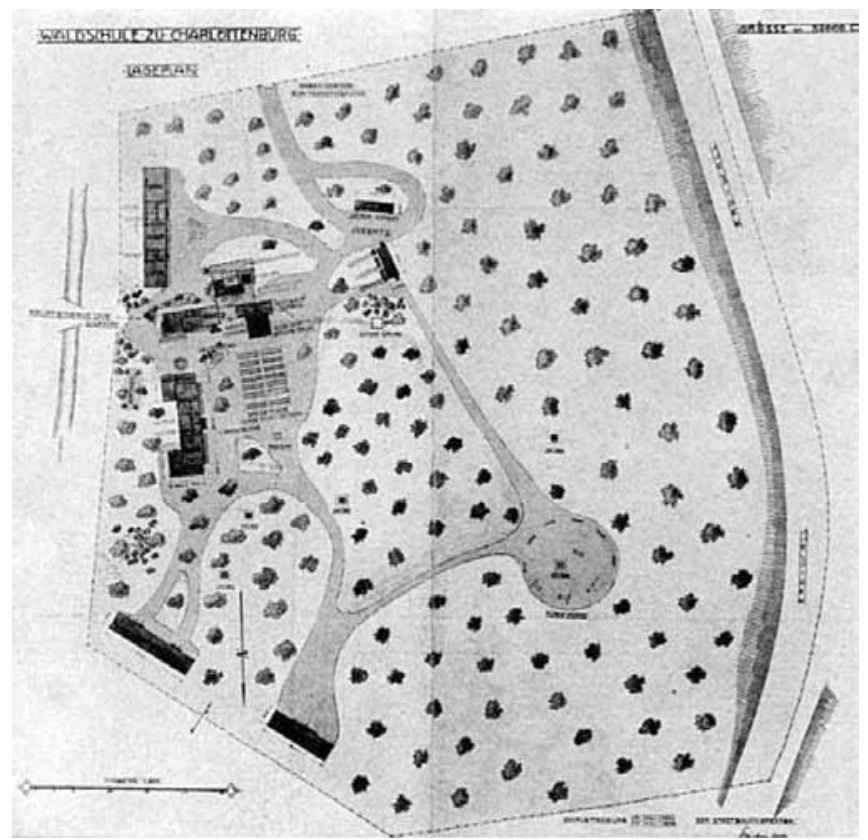

Rys. 1. Plan założenia szkoły Waldschule w Berlinie - Charlottenburg z 1904 roku autorstwa W. Spickendorfa ${ }^{2}$

Źródło: Chatelet 2008: 109.

2 Zalesioną działkę, po dokonaniu niezbędnych wycinek, uzupełniono szkołą o rozczłonkowanej, luźnej strukturze, wpisującej się doskonale w szczególny charakter przestrzeni. Rozwiązanie takie uznać należy za nowatorskie. Rysunek zorientowano zgodnie ze strzałką północy. 
W szkole zastosowano też nowatorskie metody organizacyjne - niespotykane w tamtym czasie klasy koedukacyjne, mające około dwudziestu uczniów zamiast zwyczajowych czterdziestu oraz dwu-, trzygodzinne nauczanie z przerwami co pół godziny. Również program nauczania był awangardowy - zajęcia gimnastyczne, muzyczne odbywały się na zewnątrz. Do programu wpleciono praktyczne zajęcia z ogrodnictwa - dzieci w naturze poznawały cykle przyrodnicze, zaznajamiały się z podstawami meteorologii i biologii. Nacisk kładziony był na naukę opartą na obserwacji bezpośredniej, w opozycji do tradycyjnych pośrednich metod kształcenia. Nauczyciele zachęcani byli również do stosowania autorskich sposobów nauczania oraz wspierania uczniów (Chatelet 2008: 111).

Szkoła diametralnie różniła się od ówczesnych szkół pruskich; utrzymana była w prostej, autentycznej stylistyce. Forma ta była jak najbardziej autentyczna, wynikała z potrzeby szybkiego wzniesienia budynku. Niewielkie budynki i ażurowe wiaty wykonane $\mathrm{z}$ drewna, doskonale wpisywały się w leśny krajobraz. Co warte odnotowania, na jednego ucznia przypadało około czterdziestu metrów powierzchni i było to absolutnym ewenementem w szkole pruskiej. W zasadzie każdy element przestrzeni szkolnej mniej lub bardziej konstatował tradycyjny wzorzec szkoły niemieckiej; szkoła nie posiadała wydzielonych przestrzeni dla dziewcząt i chłopców, przestrzenie do gier i zabawy były naturalne - z piasku i trawy, w odróżnieniu od powszechnie stosowanego asfaltu. Szkoła nie miała nic z reprezentacyjnego szyku, budynki nie tworzyły tak jak zazwyczaj pierzei ulicy, lecz zlokalizowane zostały zgodnie z praktycznymi wymogami - sale doświetlone od wschodu, przestrzenie do terapii od południa (Spickendorff za: Chatelet 2008: 112). Stworzona w ten sposób szkoła była rodzajem przeznaczonego na pobyt dzienny, naturalnego habitatu dla uczniów. Projekt można uznać za prekursorski w dziedzinie świadomie projektowanego środowiska edukacji.

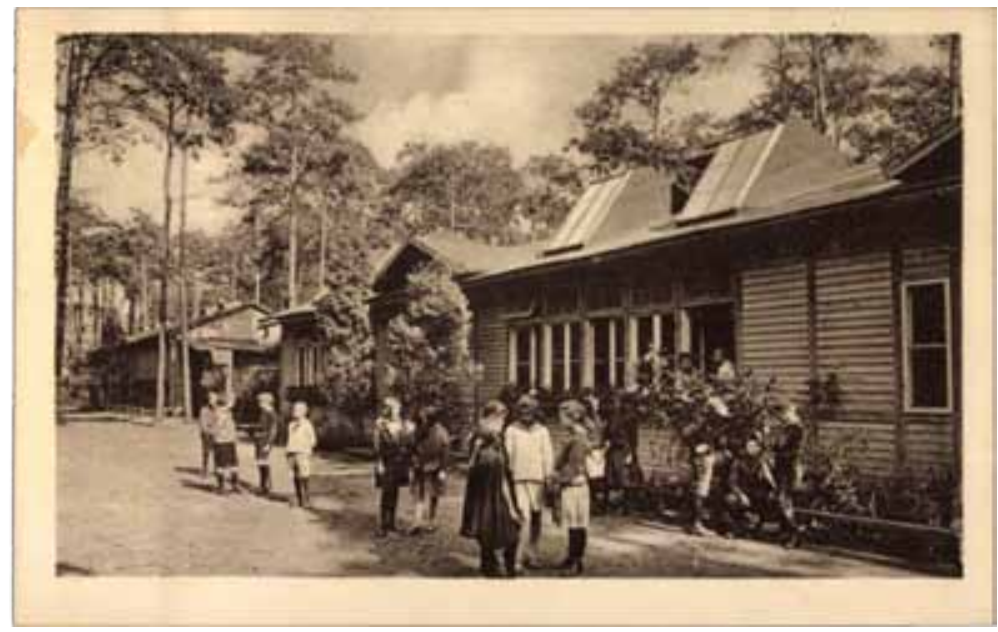

Fot. 2. Waldschule, Berlin - Charlottenburg, widok ogólny

Źródło: pocztówka z lat przedwojennych, arch. W. Spickendorff, 1904. 
Wznosząc szkołę, postawiono na ekonomię i prostotę rozwiązań, stosując parterowe budynki o konstrukcji drewnianej. Dzięki utrzymaniu skali dziecka i zastosowaniu naturalnych materiałów wykończeniowych (drewniana oblicówka elewacji), dobremu doświetleniu wnętrz (widoczne na zdjęciu świetliki dachowe) udało się uzyskać przytulny charakter budynków. Wydaje się, że bezpretensjonalna architektura Waldschule - odmienna od monumentalnej, historyzującej architektury innych obiektów oświatowych tego okresu - miała wielki wpływ na odbiór szkoły i jej akceptację przez dzieci.

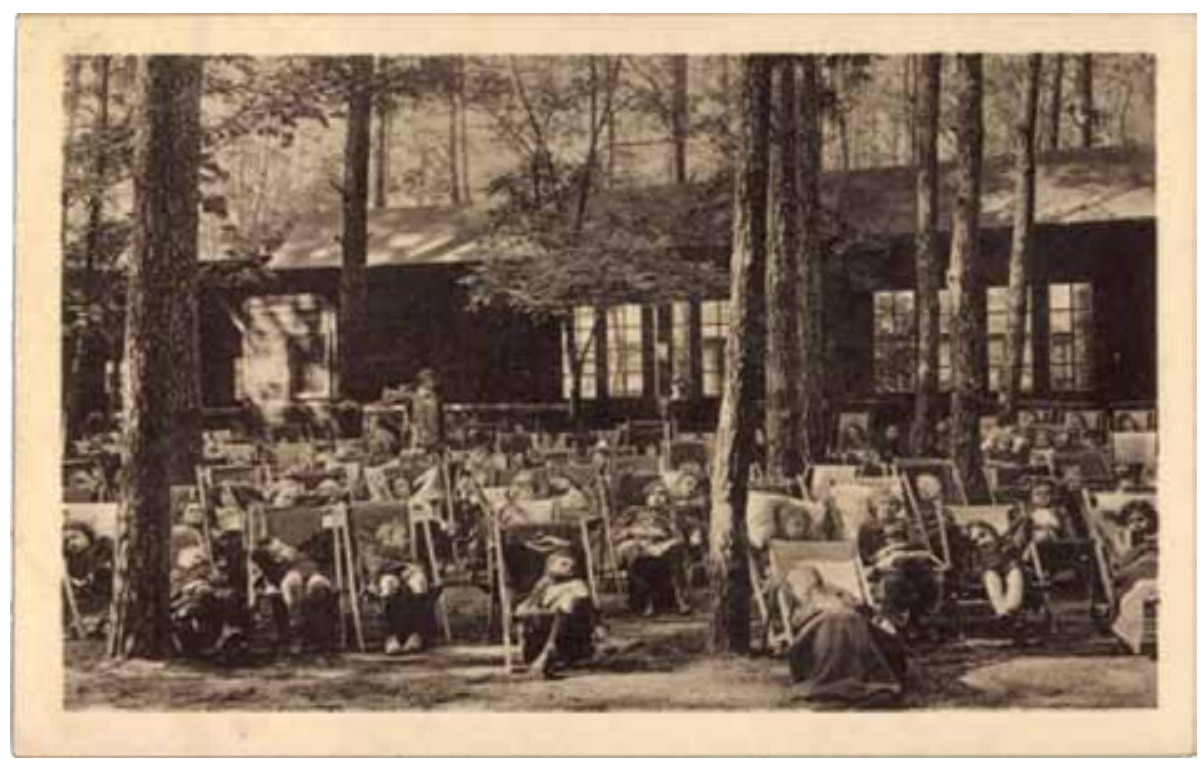

Fot. 3. Waldschule, Berlin - Charlottenburg. Grupowy odpoczynek dzieci ${ }^{3}$

Źródło: pocztówka z lat przedwojennych, arch. W. Spickendorff, 1904.

Szkoła istnieje nadal, chociaż dziś trudno doszukać się elementów pierwotnego założenia, które wielokrotnie było przebudowywane i uzupełniane o kolejne budynki. Drewniana zabudowa została poddana rozbiórce w latach 1949-59 (berlin.de 2014). Niezmienny pozostał jedynie charakter szkoły - zatopionej w zieleni i tworzącej z nią symbiotyczną całość.

\footnotetext{
3 Kąpiele słoneczne w obliczu braku lekarstw przeciw gruźlicy były jedną z niewielu znanych ówcześnie form kuracji.
} 


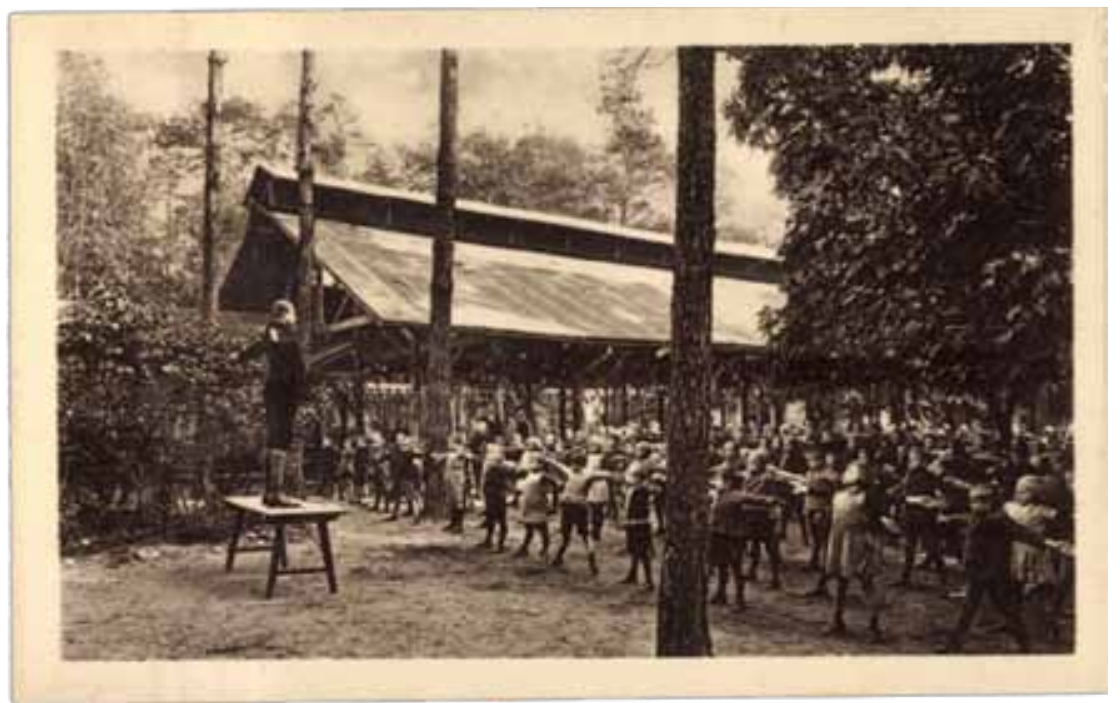

Fot. 4. Waldschule, Berlin - Charlottenburg. Grupowa gimnastyka ${ }^{4}$

Źródło: pocztówka z lat przedwojennych, arch. W. Spickendorff, 1904.

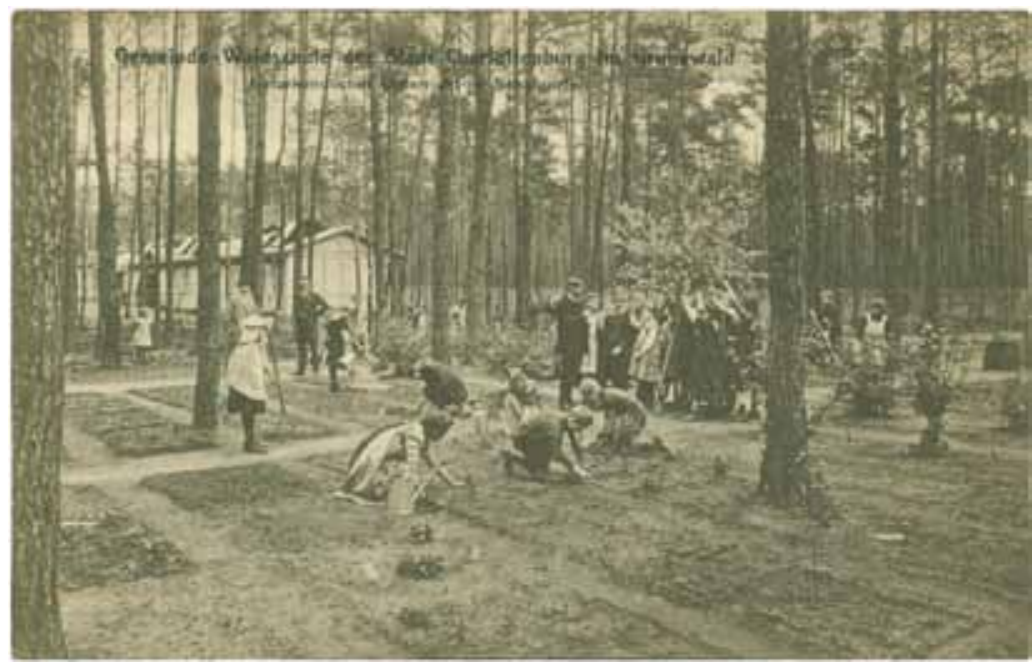

Fot. 5. Waldschule, Berlin - Charlottenburg. Zajęcia z ogrodnictwa ${ }^{5}$

Źródło: pocztówka z lat przedwojennych, arch. W. Spickendorff, 1904.

${ }_{4}$ Ćwiczenia fizyczne na świeżym powietrzu były koleją formą terapii przeciwgruźliczej. W tle widoczna jest drewniana wiata z podłużnym świetlikiem dachowym.

5 Zajęcia z ogrodnictwa były elementem nowatorskich form edukacji realizowanych w szkole, utrzymanym w duch Nowego Wychowania i uznającym praktykę za ważny element kształcenia. 


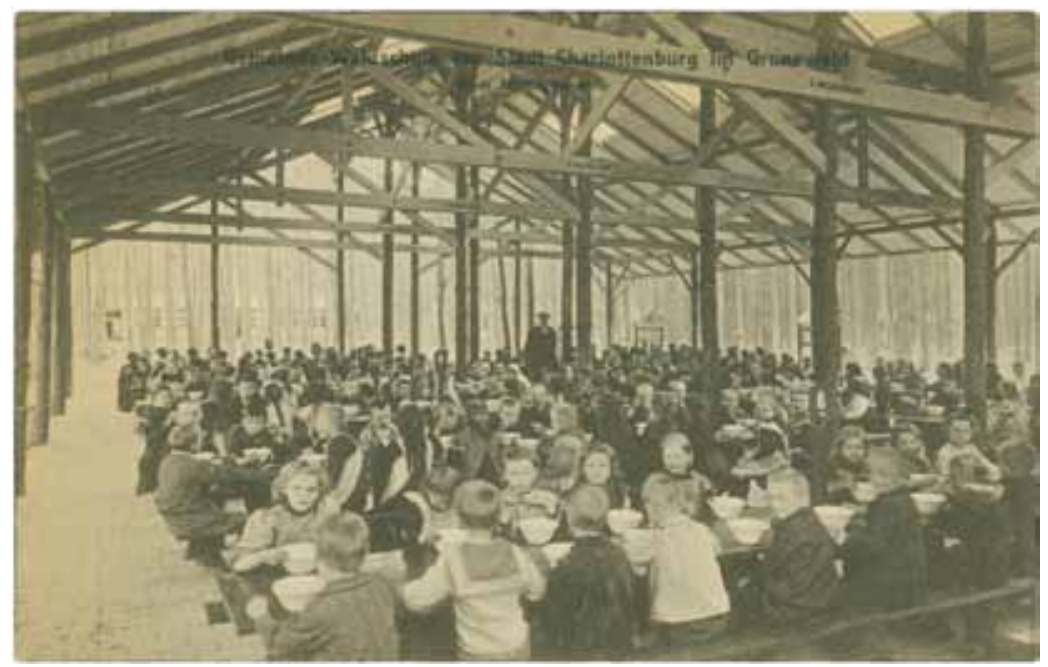

Fot. 6. Waldschule, Berlin - Charlottenburg. Wiata - „serce” szkoły ${ }^{6}$

Źródło: pocztówka z lat przedwojennych, arch. W. Spickendorff, 1904

\section{Holenderskie rozwiązanie kompaktowe}

Ikonicznym przykładem szkoły Open-Air stał się budynek zaprojektowany przez J. Duikera i A.M. Bijvoeta, wybudowany w 1930 roku w Amsterdamie. Przeznaczony został dla dzieci zdrowych jako rodzaj profilaktyki mającej w założeniu wzmacniać ich odporność. Modernistyczny budynek o dość regularnej sześciennej bryle zlokalizowany został bardzo nietypowo - wewnątrz kwartału czteropiętrowej zabudowy mieszkaniowej, obrócony względem niej o 45 stopni. W południowej pierzei kwartału znajduje się budynek wejściowy, utrzymany w zbliżonej, modernistycznej stylistyce. Szkoła przewidziana była dla 240 dzieci (8 klas po 30 uczniów). Rzuty typowych kondygnacji składają się z pionu komunikacyjnego (w części północnej), dwóch osłoniętych całkowicie przeszklonymi ścianami osłonowymi sal, doświetlonych od południowego wschodu i południowego zachodu oraz zadaszonego tarasu, pełniącego funkcję otwartej sali do nauki. Część administracyjna i sportowa zlokalizowane są na parterze. Płaski stropodach pełni również funkcję sali na otwartym powietrzu. Budynek ma konstrukcję słupową, o rozstawie 7,80 na 7,80 metrów, $\mathrm{z}$ uwolnionymi narożami. Ma to kluczowe znaczenie dla odbioru budynku jako otwartego na otaczającą go przestrzeń wewnątrzkwartałową. Wysokość pomieszczeń wynosi 3,40 m. Szkoła jest jednym z niewielu przykładów z tego okresu, które swą pierwotną funkcję pełnią do dnia dzisiejszego. Budynek jest doskonale zachowany, w 2010 roku został odrestaurowany, odtworzono między innymi pierwotną stolarkę o barwie błękitu pruskiego.

\footnotetext{
6 Pod wiatą dzieci spożywały posiłki, odbywała się tu również część zajęć w okresie niepogody. Zwraca uwagę dbałość o detale - las nieokorowanych słupów stanowiących konstrukcję wiaty nawiązuje do naturalnego otoczenia szkoły, dając wrażenie dachu zamocowanego na drzewach.
} 


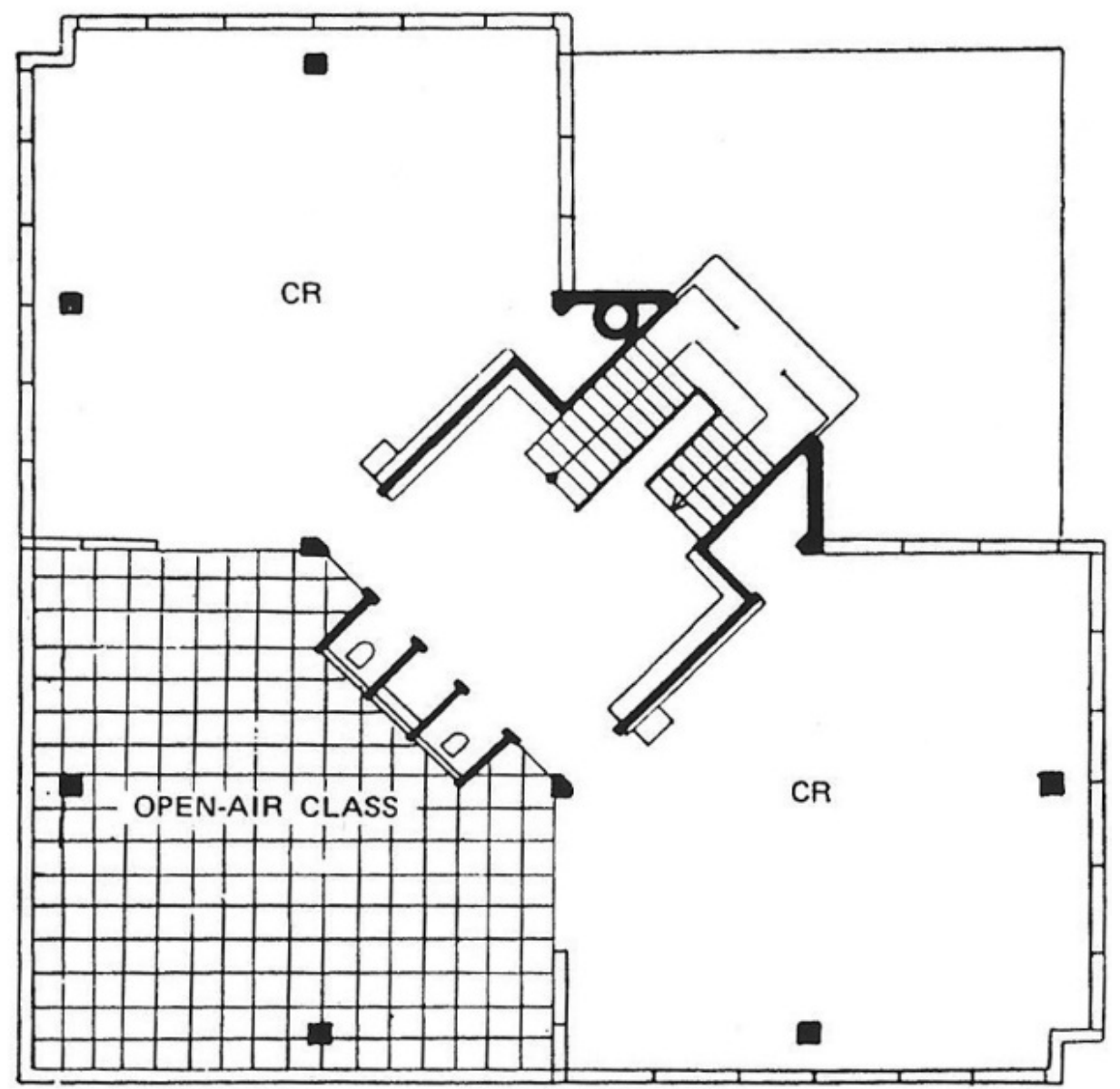

Rys. 2. Szkoła Open-Air w Amsterdamie, arch. J. Duiker, A.M. Bijvoet, 1930, rzut piętra typowego Źródło: http://www.urbipedia.org, lic. CC.

Budynek ma bardzo zwartą bryłę, nie tracąc przy tym nic ze swojego otwartego charakteru. Autor - J. Duiker - określił go mianem ,szklanej szafy”, architekturą łączącą sprzeczne wydawałoby się wymagania - transparentność i kompaktowość (Chatelet 2008: 118). Dzięki swemu wizjonerskiemu wyrazowi architektonicznemu i nowatorskim rozwiązaniom stał się inspiracją dla wielu innych europejskich szkół (Burke, Grosvenor 2008: 69).

Wolnostojąca, modernistyczna i ekspresyjna bryła budynku wciąż imponuje. Renowacja z 2010 roku przywróciła szkole pierwotny wygląd. Szkoła funkcjonuje do dzisiaj.

Na fotografii 8 widać wnętrze sali lekcyjnej z widocznym systemem otwierania okien, w tle widoczne są dachy kamienic kwartału, wewnątrz którego wzniesiono szkołę. 


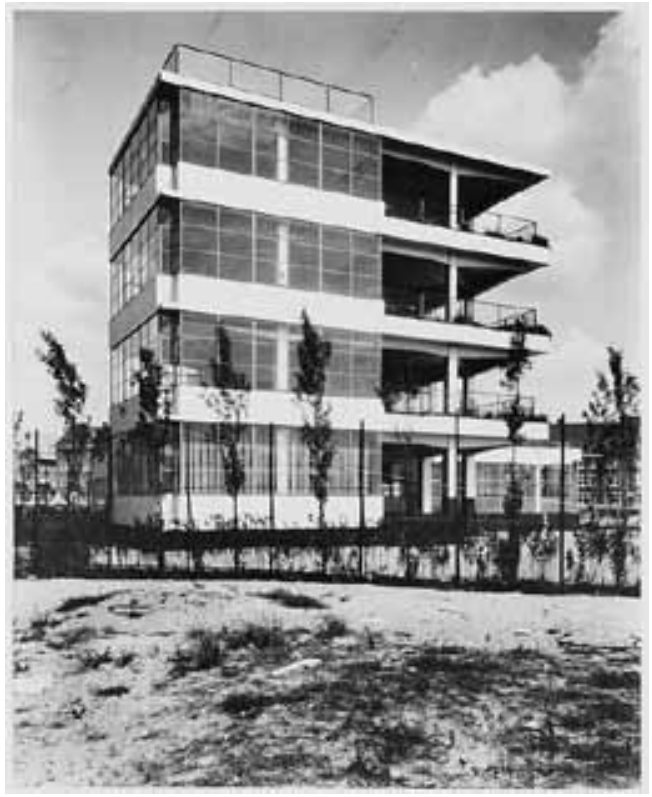

Fot. 7. Szkoła Open-Air w Amsterdamie, arch. J. Duiker, A.M. Bijvoet, 1930 Źródło: archiwum NAI.

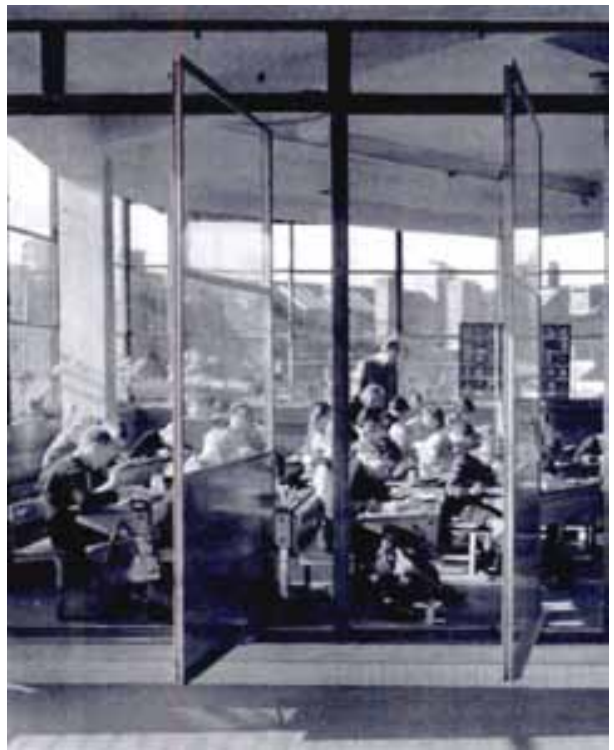

Fot. 8. Szkoła Open-Air w Amsterdamie, arch. J. Duiker, A.M. Bijvoet, 1930 Źródło: archiwum NAI. 


\section{Francuskie rozwiązanie pawilonowe}

Odmiennym przykładem i dobrze ilustrującym różnorodność metod rozwiązań szkół typu Open-Air jest szkoła we francuskim Suresnes (w zachodniej części aglomeracji Paryża). Zlokalizowana na zboczu góry Valerien, została zaprojektowana w 1935 roku przez Eugèna Beaudouina i Marcela Lodsa. Budynek powstał w przy współpracy architektów, pedagogów, pracowników socjalnych i władz lokalnych i może uchodzić za jeden z pierwszych na szeroko zakrojoną skalę przykładów projektowania partycypacyjnego.

Działkę szkoły od strony północno - zachodniej ogranicza podłużny, dwustumetrowy, dwukrotnie łamany budynek wejściowy. Osłania on teren od wiatru i wydziela obszar szkoły. Zorganizowana w nim została funkcja „społeczna” szkoły i administracja. W środkowej części trójsegmentowego budynku znajduje się wejście, flankowane przez model Ziemi ze spiralnie wijącymi się wokół niej schodami, który był wizytówką placówki. Północna elewacja jest zamknięta, z bardzo ograniczoną ilością perforacji, zdobiona otoczakami. Południowa natomiast jest prawie w całości transparentna, wyposażona w modernistyczne, ogromnej wielkości okna pasowe. Po przeciwnej stronie dziedzińca zlokalizowany został pawilon szpitalny, a pomiędzy nim a budynkiem głównym rozlokowano promieniście osiem pawilonów lekcyjnych o wymiarach 8,80 na 6.00 metrów i wysokości 4 metry. Struktura ich elewacji była podobna do fasady budynku głównego - północna ściana zaprojektowana jako ślepa, pokryta kamienną mozaiką, pozostałe trzy ściany jako zsuwane przeszklenie. W pawilonach zaprojektowano nowatorskie w tamtym czasie rozwiązania techniczne: obwodowe ogrzewanie kanałowe, działające w zimie na zasadzie kurtyny powietrznej oraz całkowicie zsuwane za pomocą specjalnego mechanizmu przeszklenie ścian. Szkołę wyposażono również w specjalnie zaprojektowane meble na giętym stelażu aluminiowym. Cała konstrukcja wykonana była ze stali i szkła (Chatelet 2008: 118-122).

Szkoła została otwarta w 1935 roku, na podstawie badań lekarskich przyjęto 211 uczniów. Dzieci miały nie więcej niż cztery godziny zajęć dziennie. Resztę przeznaczano na rekreacje, zabawę i posiłki. Stosowano program pedagogiczny Nowoczesnej Szkoły Francuskiej stworzonej przez C. Freineta, utrzymanej w duchu Nowego Wychowania. Dzieci poznawały świat poprzez rozwijanie indywidualnych zdolności twórczych, swobodną ekspresję i własne doświadczenia (pozytywne i negatywne), bez tradycyjnych metod kontroli i oceniania ucznia (Sztobryn 2003: 358-360). Ważnym elementem programu było całoroczne obserwowanie zmieniającej się przyrody. W wywiadach, które przytacza A.M. Chatelet, wychowankowie podkreślają, że ówcześni uczniowie uwielbiali szkołę, [dzieci - C.S.] ,płakały wsiadając wieczorem do autobusu” (Chatelet 2008: 122). Szkoła podobała się również rodzicom. Podziwu dla architektów i władz lokalnych nie kryje w swoich wspomnieniach S. Lacater, pierwszy dyrektor placówki, zastanawiając się nad sprawczą rolą, jaką odegrała architektura dla funkcjonowania szkoły: „Zastanawiasz się, jak to możliwe, że (...) byli w stanie zaaplikować nowoczesne i racjonalne metody edukacji po prostu przez program funkcjonalny i dyspozycję przestrzenną budynku" (Lacapere 1978: 8-9 za: Chatelet 2008: 122). Szkoła działała do 1995 roku, kilka lat później uznana została za zabytek kultury. To jednak nie zmieniło jej sytuacji - obecnie jest w złym stanie technicznym, nieremontowana ulega dalszej degradacji. 


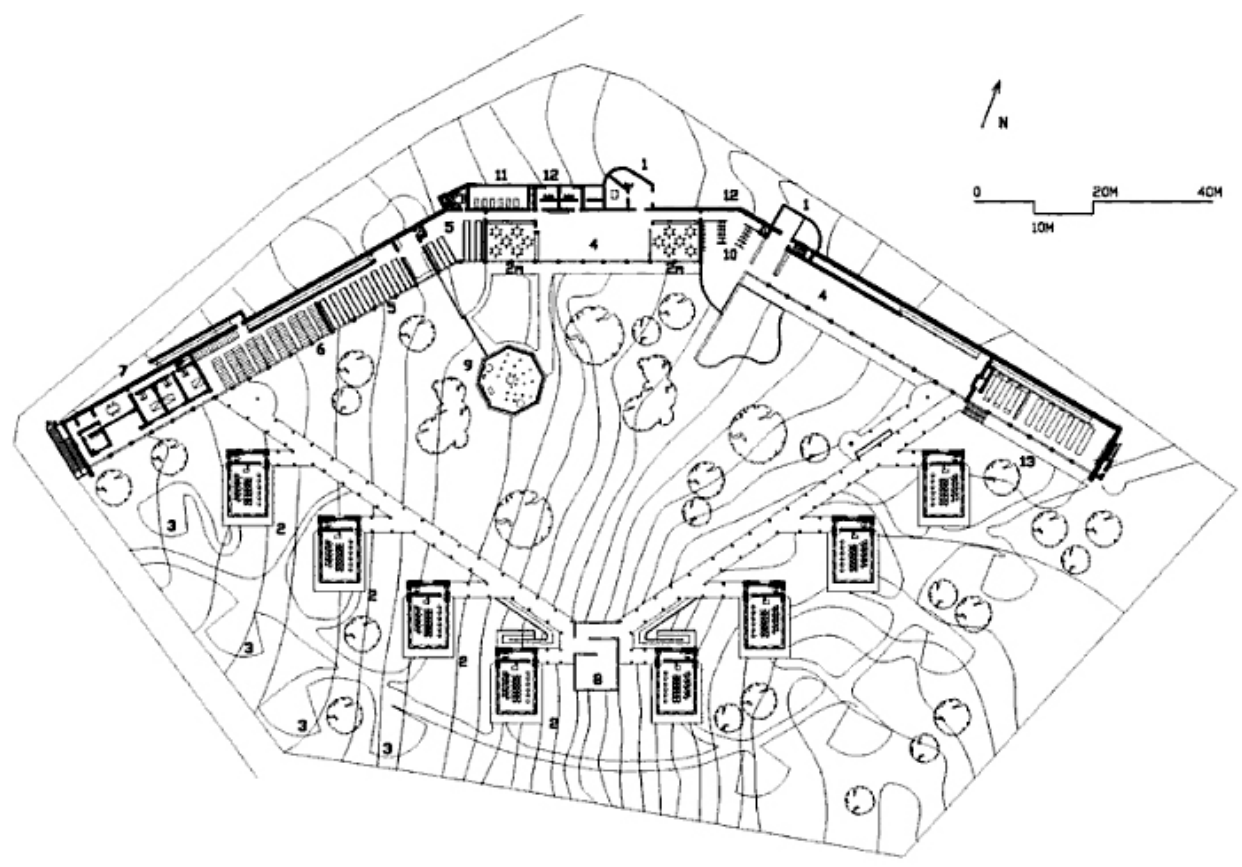

Rys. 3. Szkoła Open-Air w Surensnes, arch. E. Beaudouin, M. Lods, 1931-19357

Źródło: Centre d'archives d'architecture du xxe siècle, http://www.citechaillot.fr.

Zdjęcia szkoły z okresu jej działalności do dzisiaj wyglądają zadziwiająco nowocześnie. Wykreowana przez architektów przestrzeń wydaje się być doskonałym wzorcem integracji szkoły z naturą. Wyraźnie widoczne jest zamierzenie architektów, by zatrzeć granicę pomiędzy architekturą a otaczającą ją zielenią. Imponują odważne rozwiązania techniczne budynku i doskonałe wpisanie budynku w kontekst zadrzewionego stoku.

Szkoły Open-Air były mocno kojarzone ze swym prozdrowotnym wymiarem. Z czasem odkrycie leków przeciwgruźliczych spowodowało osłabienie ruchu propagującego ideę budowy tego typu placówek. Jednak osiągnięcie, jakim była ekspozycja szkoły na środowisko zewnętrzne, rozwiązania w postaci balkonów, tarasów, wielkorozmiarowych otwarć, zatarcie granicy pomiędzy wnętrzem i zewnętrzem, przetrwały i były w późniejszych rozwiązaniach poddawane przeróżnym interpretacjom.

\footnotetext{
7 Rzut parteru: 1 - wejście; 2 - pawilony do nauki; 3 - placyki - do nauki na zewnątrz; 4 - hol; 5 - kuchnia i stołówka; 6 - sala do wypoczynku; 7 - administracja; 8 - pawilon medyczny; 9 - pawilon nauki dzieci niepełnosprawnych intelektualnie; 10 - basen kryty i otwarty; 11 - sala do terapii; 12 - szatnia $\mathrm{z}$ umywalnią; 13 - warsztat do nauki indywidualnej i odrabiania prac domowych.
} 


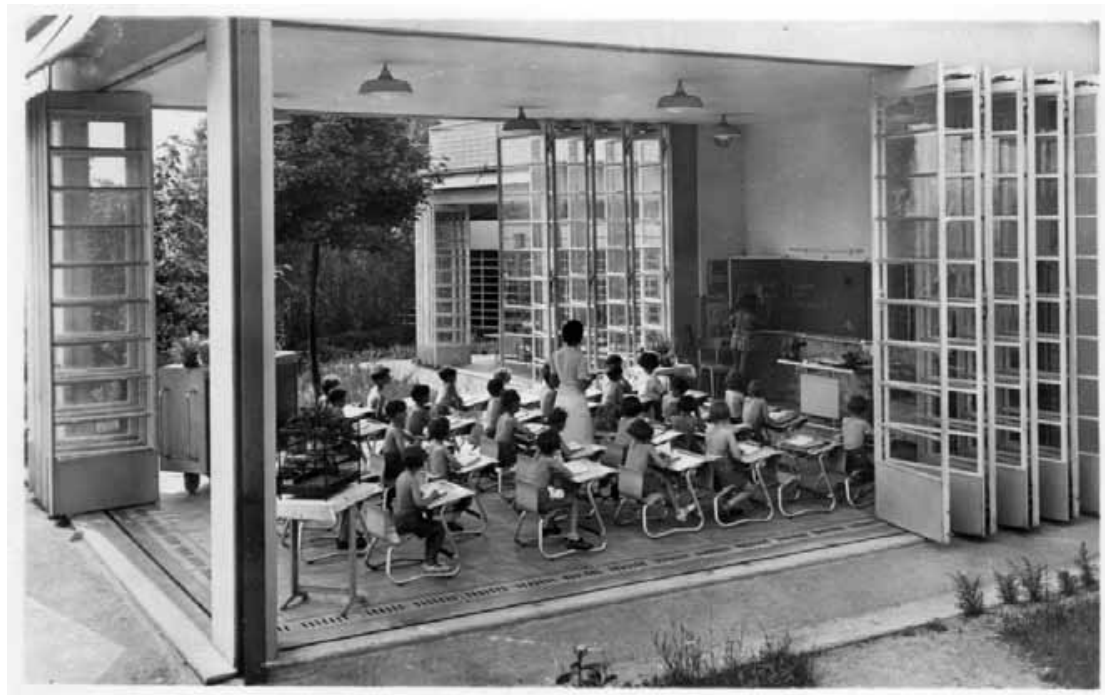

Fot. 9. Szkoła Open-Air w Surensnes, jeden z ośmiu wolnostojących pawilonów ${ }^{8}$

Źródło: Centre d'archives d'architecture du xxe siècle, http://www.citechaillot.fr.

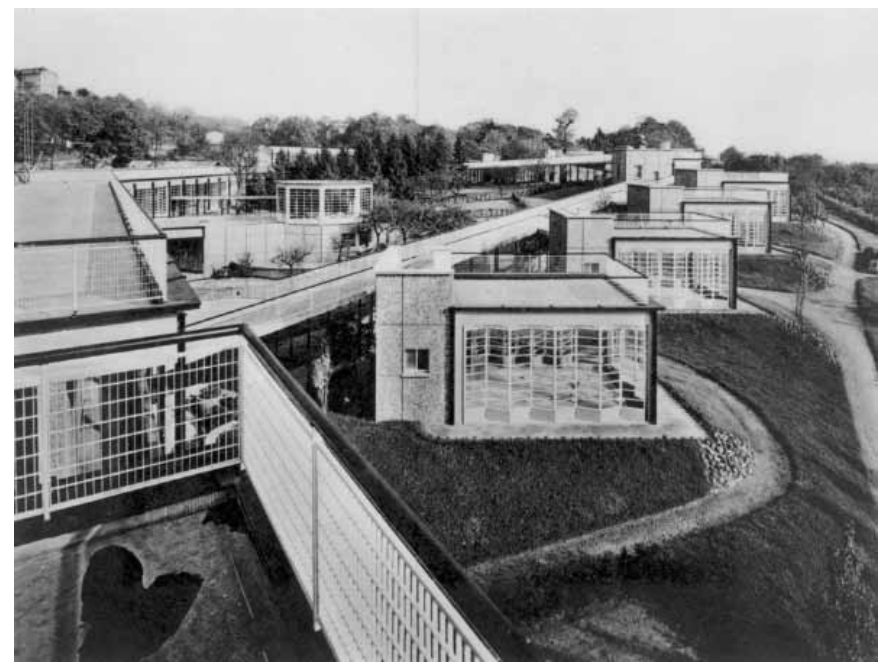

Fot. 10. Szkoła Open-Air w Surensnes, widok na założenie z balkonu, widoczne dwa poziomy komunikacji - tarasy nad pawilonami połączone były estakadą pieszą, z której roztaczał się widok na cały obszar szkoły

Źródło: pocztówka z lat przedwojennych.

${ }^{8} \mathrm{Na}$ zdjęciu widoczne są bardzo zaawansowane ówcześnie rozwiązania techniczne - całkowicie przesuwna ściana osłonowa i ogrzewanie kanałowe. 


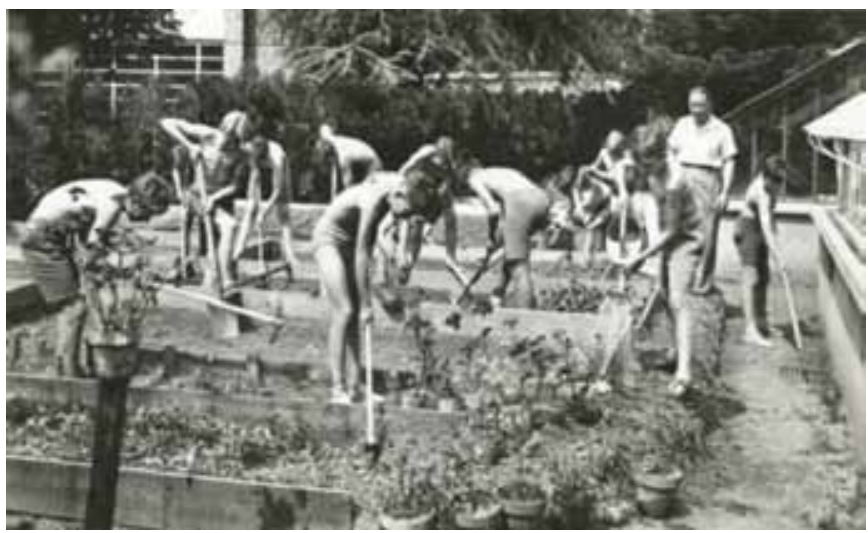

Fot. 11. Szkoła Open-Air w Surensnes, zajęcia praktyczne z ogrodnictwa - w szkole realizowano nowatorski program pedagogiczny C. Freineta

Źródło: pocztówka z lat przedwojennych.

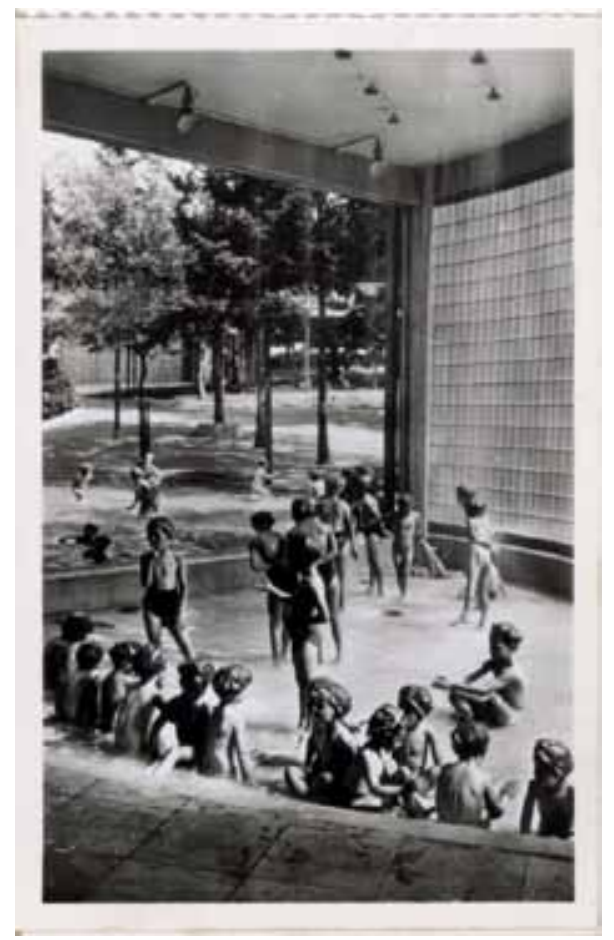

Fot. 12. Szkoła Open-Air w Surensnes, rekreacja w basenach szkolnych - szkoła posiadała wyjątkowo rozbudowany, jak na ówczesne standardy, program rekreacyjno-sportowy, do którego przykładano dużą wagę

Źródło: pocztówka z lat przedwojennych. 


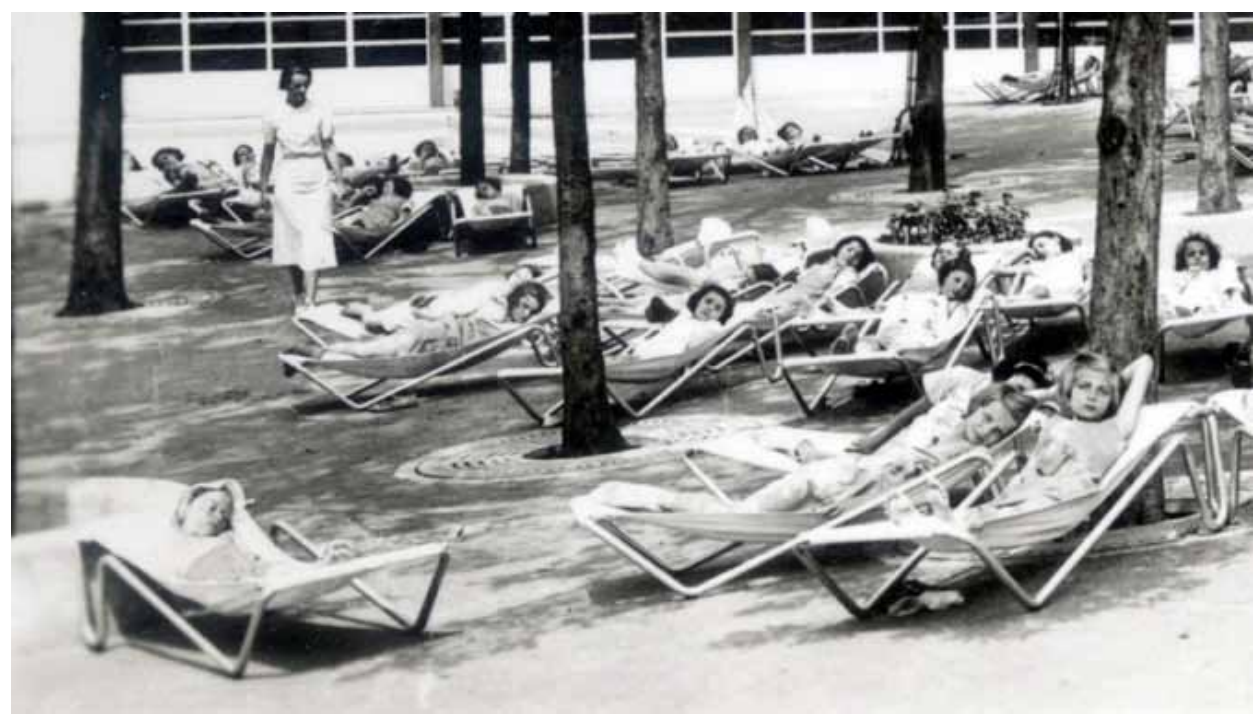

Fot. 13. Szkoła Open-Air w Surensnes, odpoczynek dzieci na zadrzewionym dziedzińcu szkolnym. Uwagę zwracają specjalnie zaprojektowane dla szkoły leżaki. Razem z pozostałymi elementami wyposażenia tworzyły niepowtarzalną serię

Źródło: pocztówka z lat przedwojennych.

\section{Rozwiązanie kompromisowe}

Otwartość szkół Open-Air była realizowana na różne sposoby. W okresie, w którym powstawały, można zauważyć poszukiwania architektów w kierunku znalezienia wzorcowego modelu, zapewniającego zarówno spełnienie postulatów funkcjonalnych (np. dwustronne przewietrzanie, najlepiej realizowane w szkołach składających się z wolnostojących pawilonów), jak i wykorzystanie zalet, jakie daje kompaktowy, znacznie tańszy w budowie i utrzymaniu budynek (w okresie powstawania szkół tego typu wielkim ograniczeniem była chociażby kwestia dogrzania wolnostojących pawilonów). Przedstawione przykłady należą do najbardziej wizjonerskich projektów szkół typu Open-Air. Zauważyć należy, że najczęściej poszukiwano jednak rozwiązań pośrednich - kompromisowych i z pewnością nie tak widowiskowych. Typowym rozwiązaniem dla tego nurtu może być szkoła w holenderskim Arnhem z 1930 roku, autorstwa H.B. van den Broekhuizena, zaprojektowana jako układ trzech pawilonów połączonych traktem komunikacyjno - sanitarnym, każda z sal w szkole była dwustronnie przewietrzana i doświetlona $\mathrm{z}$ trzech stron. 


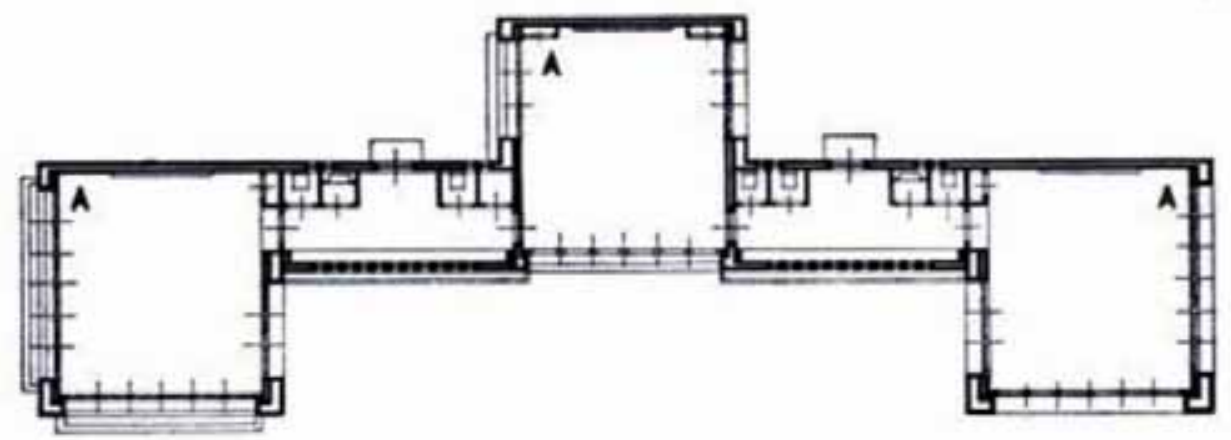

Rys. 4. Szkoła Open-Air w Arnhem zaprojektowana przez H.B. van den Broekhuizena

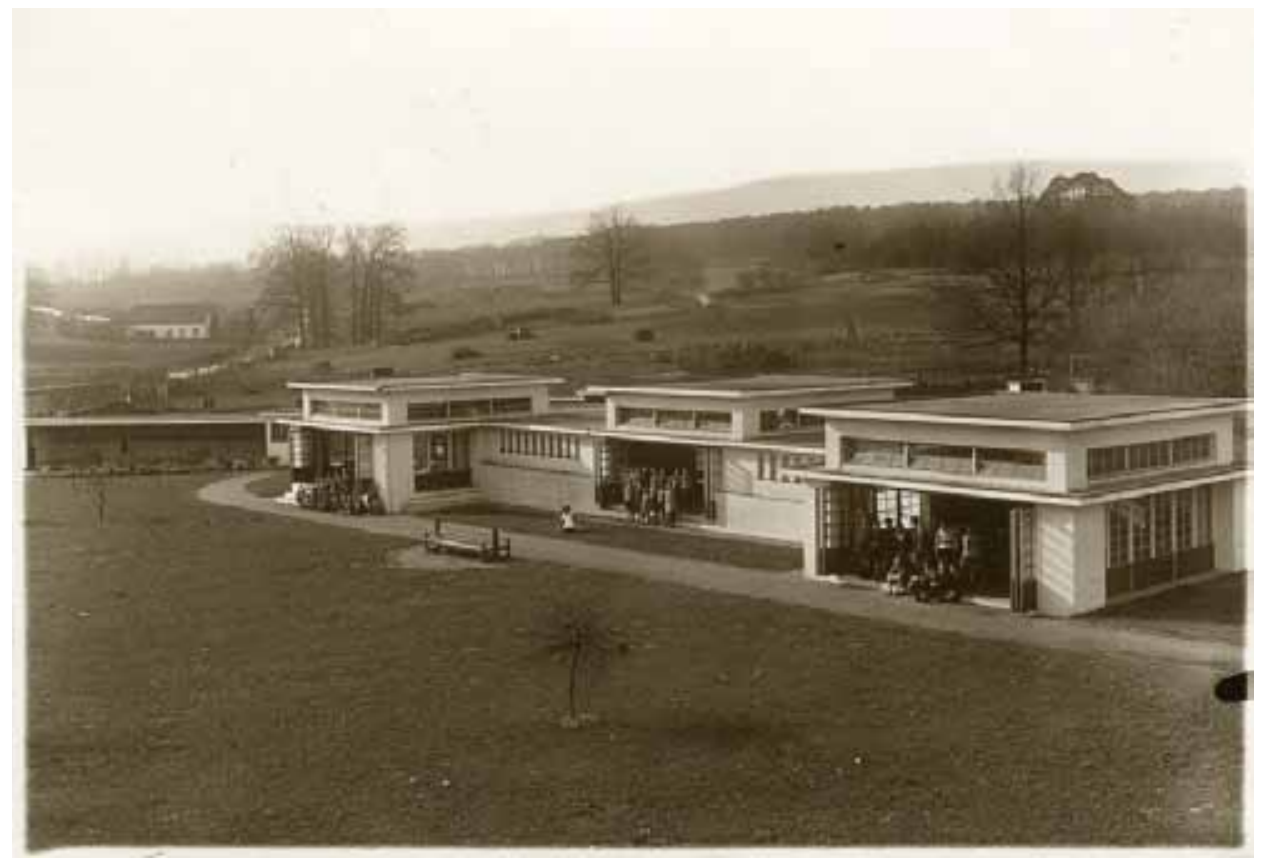

Fot. 14. Szkoła w Arnhem, arch. H.B. van den Broekhuizen

Źródło: archiwum NAI.

Szkoła w Arnhem to przykład szkoły realizującej założenia Open-Air w budynku będącym rozwiązaniem pośrednim pomiędzy układem pawilonowym a kompaktowym. 


\section{Podsumowanie}

Realizacja pierwszej szkoły Open-Air (Waldschule) w Niemczech doczekała się wielu publikacji, była szeroko promowana na wielu światowych konferencjach tego czasu. Propagowane rozwiązania spotykały się z ogromnym zainteresowaniem, skutkiem czego była duża liczba realizacji, czerpiących z pierwowzoru - początkowo w Niemczech, później w Europie, trapionej tymi samymi problemami (w Wielkiej Brytanii, Francji, Holandii, Danii, Szwecji, Szwajcarii, Hiszpanii) i dalej w Stanach Zjednoczonych i Australii. Szkołom tego typu w poszczególnych krajach nadawano różne nazwy, najpowszechniej są jednak znane pod angielskim określeniem Open-Air schools (Chatelet 2008: 113).

Prawdopodobna liczba zbudowanych tego typu szkół sięga kilkuset, większość jednak nie jest powszechnie znana i w żaden sposób skatalogowana (Chatelet 2008: 117). Wyjątek stanowią szkoły w Wielkiej Brytanii, które były przedmiotem osobnych opracowań - w Wielkiej Brytanii działało 96 szkół dziennych i 53 z internatami (Worpole 2000: 50).

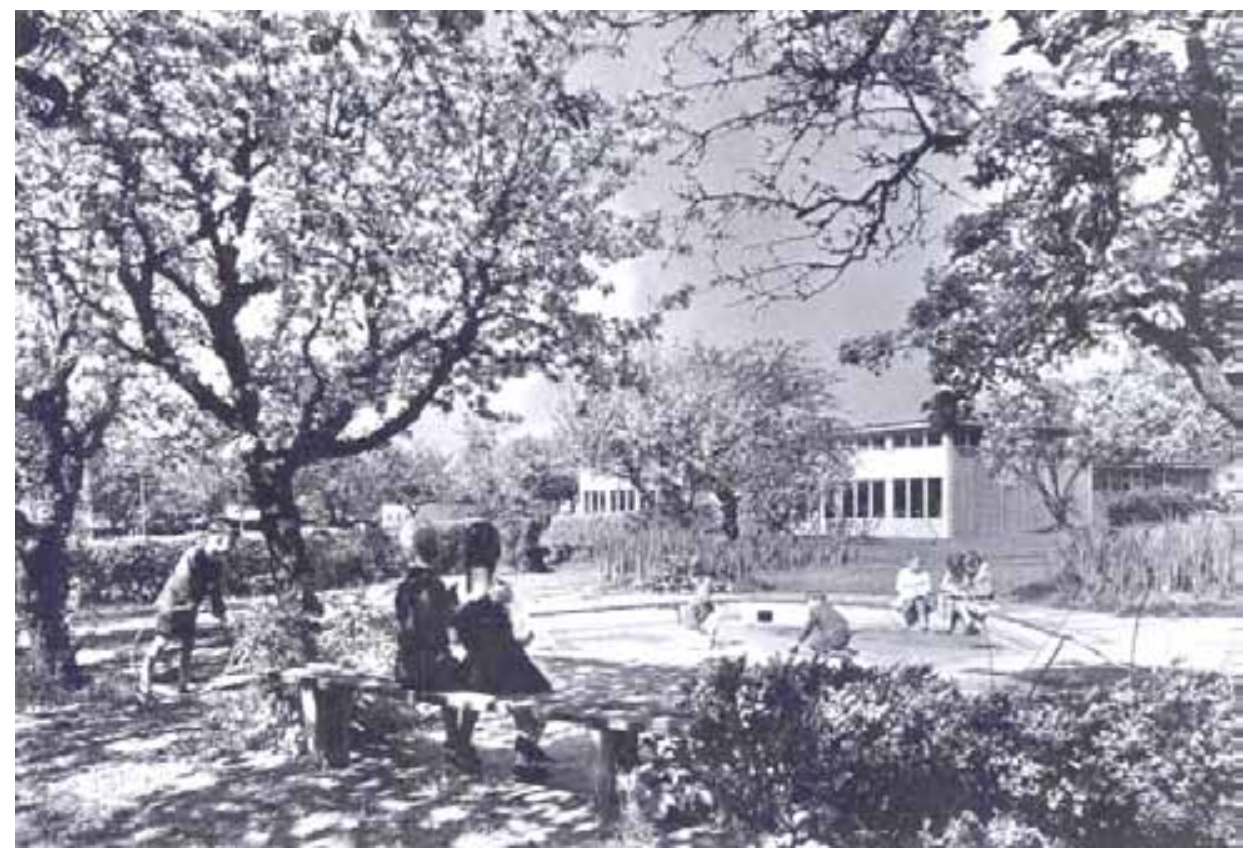

Fot. 15. Aboyne Lodge Primary School, St Albans, Anglia, 1960 rok $^{9}$

Źródło: Worpole 2000: 50.

9 Układ i sposób funkcjonowania obiektu wydaje się być reminiscencją pierwszych założeń szkół typu Open-Air. Szkoła działa do dzisiaj. 
Chociaż otwartości szkół typu Open-Air nie sposób nie odczytywać jako pragmatycznej odpowiedzi na potrzeby epoki, to idea integracji szkoły i środowiska przetrwała i obecna była w kolejnych dziesięcioleciach. Spełnienie wymogów higieny przestrzeni szkolnej stało się podstawowym i oczywistym kryterium. Za najważniejsze osiągnięcie szkół typu Open-Air uznać można jednak przeskok jakościowy - zerwanie z XIX-wiecznym kanonem w projektowaniu przestrzeni edukacji i spopularyzowanie tematu oświaty w szerszym dyskursie publicznym (Cook 2007: 65). Można również zauważyć, że szkoły tego typu i program w nich realizowany w naturalny sposób stały się polem doświadczalnym dla awangardowej myśli pedagogicznej nurtu Nowego Wychowania, a w dalszej perspektywie jednym ze stymulantów rozwoju pedagogiki jako nauki. Obecnie, co zauważa wielu wybitnych pedagogów, praktykę edukacyjną w Polsce i na świecie charakteryzuje znaczny regres, zmierzający w kierunku pedagogiki pozytywistycznej (Hejnicka-Bezwińska 2003: 204, 217), skupiającej się głównie na pamięciowym kształceniu sfery intelektualnej. Wydaje się więc, że współcześnie - gdy ze wzmożoną siłą odżywa dyskusja o kształcie i celach przyszłej edukacji - szkoły typu Open-Air nadal mogą inspirować do głębszej integracji metod i praktyk edukacyjnych ze środowiskiem architektonicznym szkoły.

Zdaniem M. Seaborne i R. Lowe szkoły Open-Air odmieniły architekturę szkół, czyniąc ją ,,interesującą, malowniczą, ale przy tym niepretensjonalną” (Seaborne, Lowe 1977 za: Cook 2007: 66). Umiejętne połączenie reprezentacyjnego charakteru budynku publicznego ze skalą i charakterem domu jednorodzinnego było znaczącym osiągnięciem w kwestii dotąd najczęściej pomijanej - percepcji środowiska szkolnego przez uczniów. Model przestrzeni szkoły proponowany jako Open-Air również współcześnie uważany jest za właściwy (Cook 2007: 67).

\section{Literatura}

berlin.de [portal internetowy miasta Berlin], http://www.berlin.de/ba-charlottenburg-wilmersdorf/ wissenswertes/lexikon/waldsch.html, dostęp 1.04. 2014.

Burke K., Grosvenor I. (2008), School. London, Reaktion Books.

Bać A. (2003), Wybrane zagadnienia projektowania szkół na przykładzie realizacji wiedeńskich lat 90. XX wieku, Wrocław, niepublikowana rozprawa doktorska obroniona na Wydziale Architektury Politechniki Wrocławskiej.

Chatelet A.M. (2008), A Breath of Fresh Air: Open-Air Schools in Europe. W: M. Gutman, N. de Coninck-Smith (red.), Designing Modern Childhoods History Space, and the Material Culture of Children, New Brunswick, Rutgers University Press.

Cook M. (2007), The Design Quality Manual: Improving Building Performance. Oxford, Blackwell Publishing.

Crowley R.H. (1910), The Hygiene of School Life. London, Methuen and Co.

Driessche, van den, M. (2007), The journey of children..., "OASE Journal for Architecture: Back to School", 72 . 
Drzewiecki P., Przestrzeń dla edukacji. O architekturze szkolnej, http://www.edunews.pl/badania-i-debaty/opinie/820, dostęp 7.02. 2014.

Hejnicka-Bezwińska T. (2003), Współczesne prądy i kierunki pedagogiczne. Pedagogika pozytywistyczna. W: Z. Kwieciński, B. Śliwerski (red.), Pedagogika. Podręcznik akademicki. T. 1, Warszawa, PWN.

Illich I. (2010), Odszkolnić społeczeństwo. Warszawa, Bęc Zmiana.

Robinson (red.) (1999), All Our Futures: Creativity, Culture and Education. National Advisory Committee on Creative and Cultural Education. Londyn, Dept. for Education and Employment.

Okoń W. (2004), Nowy stownik pedagogiczny. Warszawa, Wydawnictwo Akademickie ŻAK.

Lacapere S. (1978), Souvenirs de la maison de verre. L'ecole de plein air de Suresnes, communaute educative. Paris, L'Amitié par le livre.

Pallasmaa J. (2012), Oczy skóry. Architektura i zmysty. Kraków, Instytut Architektury.

Prokopska A. (2002), A Methodological Analysis of Selected Morphological Systems of the Natural and Architectural Environments. "Journal of Transdisciplinary Systems Science".

Prokopska A. (2002), Morfologia dzieła architektonicznego. Analiza metodologiczna wybranych morfologicznych układów środowisk naturalnego i architektonicznego. Rzeszów, Oficyna Wydawnicza Politechniki Rzeszowskiej.

Robinson K. (2010), Oblicza umystu. Kraków, Wydawnictwo Element.

Rittelmeyer Ch. (1994), Schulbauten positiv gestalten. Wie schueler farben und formren Erleben. Wiesbaden-Berlin, Bauverlag.

Seaborne M., Lowe R. (1977), The English school: It's architecture and organisation, 1870-1970. Volume II, London, Routledge \& Kegan Paul.

Śliwerski B. (2013), Zmierzamy ku edukacyjnej katastrofie [rozmowa z R. Drzewieckim], „Dziennik Gazeta Prawna", 26.04. 2013.

Ślusarczyk M. (2010), Spory o edukację wczoraj i dziś. Społeczny, polityczny i kulturowy kontekst reform oświatowych - porównanie Polski i Niemiec. Kraków, Oficyna Wydawnicza AFM.

Sztobryn S. (2003), Pedagogika Celestyna Freineta. W: Z. Kwieciński, B. Śliwerski (red.), Pedagogika. Podręcznik akademicki. T. 1, Warszawa, PWN.

Wallenstein S.O. (2009), Biopolitics and the Emergence of Modern Architecture. New York, Buell Center \& Princeton Architectural Press.

Włodarczyk J. (1992), Architektura szkoły. Warszawa, Arkady.

Wołoszyn S. (2003), Oświata i wychowanie w XX wieku. W: Z. Kwieciński, B. Śliwerski (red.), Pedagogika. Podręcznik akademicki. T. 1, Warszawa, PWN.

Worpole K. (2000), Here Comes the Sun. Architecture and Public Space in Twentieth-Century European Culture. London, Reaktion Books. 